\title{
Single Nucleotide Polymorphism of Calcitonin Receptor Gene in South Indians
}

\author{
M. Lekha Menon and Bharathi \\ Jain Institute of Vocational and Advanced Studies, 127/3, Bull Temple Road, \\ Chamrajpet, Bangalore 560 019, Karnataka, India \\ Telephone: 080 - 22425246, E-mail: lekha513@gmail.com
}

KEYWORDS Calcitonin receptor gene; SNP; polymorphisms

\begin{abstract}
Two alleles of the calcitonin receptor gene exist: a base mutation T->C in the third intracellular Cterminal domain changes a proline (CCG) to a leucine (CTG). The Codon 447 polymorphism of CTR gene was studied in 9 normal unrelated individuals from South India. The genomic DNA was isolated, CTR gene was amplified and the PCR products were subjected to restriction digestion. We have found that the C/T alleles show a $33.33 \%$ indicating that the individuals are protected against calcium related disorders.
\end{abstract}

\section{INTRODUCTION}

Calcitonin is a 32 amino acid peptide hormone produced in the $\mathrm{C}$ cells of mammalian thyroid and plays an important physiological role in calcium homeostasis (Copp 1992). The hormone acts on its target cells via calcitonin receptors (CTR) which belong to class II of G-protein coupled receptors (Chen et al.1997). Lin et al. (1991) has extensively studies that the human calcitonin receptor is coded by CTR gene on 7q 21.3. Calcitonin is a hormone implicated in bone resorption and acts through specific receptors present in large numbers in the osteoclasts (Chambers and Magnus 1982). This hormone decreases bone resorption and is therefore used to treat osteoporosis (Reginster 1993). According to Nakamura et al. (1997) there is a C/T variation at nucleotide 1340 of CTR gene which causes a change in amino acid from proline to leucine . This change occurs at 28th amino acid from the $\mathrm{C}$ terminal in the cytoplasmic domain of the protein. Previously, studies have been carried out in different populations (Chen et al. 2001). Mittal et al. (2003) carried out studies of alleic polymorphisms in North Indian populations. However, there are no reports of allelic variations from South Indians where populations are quite different. Therefore, the present study has been carried out to determine the allelic frequency of the CTR gene in South India.

\section{MATERIALS AND METHODS}

Blood samples were collected from 9 unrelated normal healthy individuals (people with no significant disorder), mostly from staff and stu- dents of our institute. The blood samples were collected in EDTA containing vials and kept at $20^{\circ} \mathrm{C}$ until DNA extraction. The genomic DNA was isolated using the protocol specified in the FBI RFLP Manual (1993).

Polymerase Chain Reaction: PCR analysis of CTR gene polymorphism was carried out to a total volume of $25 \mu \mathrm{l}$, containing $2.5 \mu \mathrm{l}$ of genomic DNA; 1 pmol of $1 \mu$ l of each primer; $1 X$ of 2.5 il of Taq polymerase buffer and 1 unit of 0.4 il of Taq DNA polymerase(SBL, India). The primer for the calcitonin receptor gene polymorphism were forward (5'- CTCAGTGATCACGATACTGTG-3') and reverse (5' -ATTCAGTGGAACCAGCGTTGG-3') (Masi et al. 1998). PCR amplification was performed in a programmable thermal cycler PTC-100 (Peltier Thermal Cycler, MJ Research). In context with Mittal et al.(2003) the cycling condition was set as follows: $94^{\circ} \mathrm{C}$ for $5 \mathrm{~min}, 35$ cycles at $95^{\circ} \mathrm{C}$ for $30 \mathrm{~s}, 55^{\circ} \mathrm{C}$ for $30 \mathrm{~s}$ and $72^{\circ} \mathrm{C}$ for 30 s and one cycle of extension at $72^{\circ} \mathrm{C}$ for $10 \mathrm{~min}$.

Alu I Restriction Digestion: The PCR product was incubated with 1.5 units of Alu I (Bangalore Genei, India) at $37^{\circ} \mathrm{C}$ for $3 \mathrm{hr}$, using the buffer supplied by the manufacturer. The digested product was separated on $12 \%$ polyacrylamide gel electrophoresis (PAGE) and photographed using Herolab, gel documentation system, Japan. The sizes were determined using 100bp ladder (Bangalore Genei, India).

After electrophoresis, the gel was stained with ethidium bromide. The restriction site is located at the CTG codon encoding the amino acid leucine forming a cuttable site . Codon CCG encoding the amino acid proline will remain intact (228 bp). If the product was excisable, two fragments of 120 and 108bp will be present. (Sambrook et al. 1989) 


\section{RESULTS}

The genomic DNA of the blood samples showed a single band. (Fig.1, 2). The PCR product showed a single band between 200 and 300 bp. (Fig.3, 4). When the PCR products were subjected to restriction digestion with Alu I two pat-

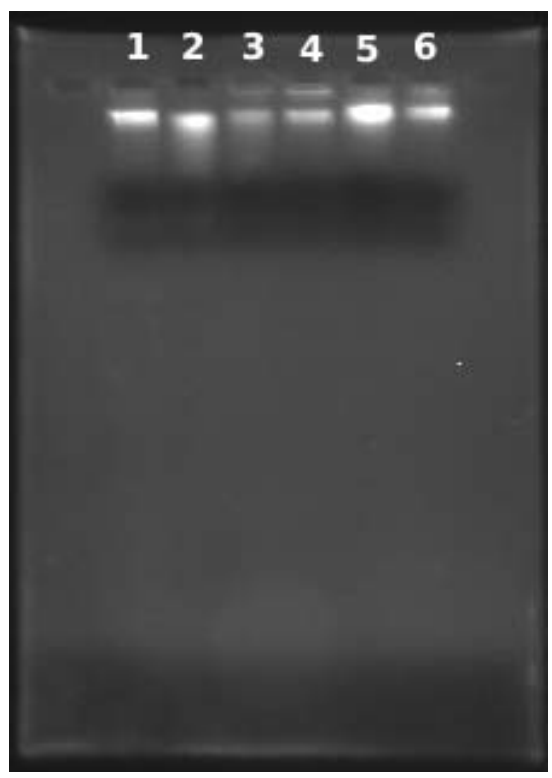

Fig. 1. Genomic DNA of blood samples 1 to 6

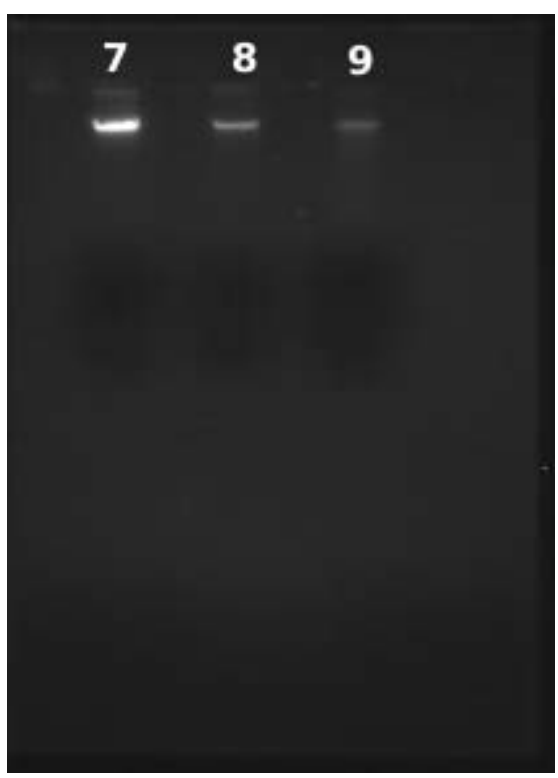

Fig. 2. Genomic DNA of blood samples 7 to 9 terns were observed: 228bp; 228bp, 120 and 108bp corresponding to $\mathrm{C}$ homozygotes and $\mathrm{C} / \mathrm{T}$ heterozygotes respectively. C/T genotypes were

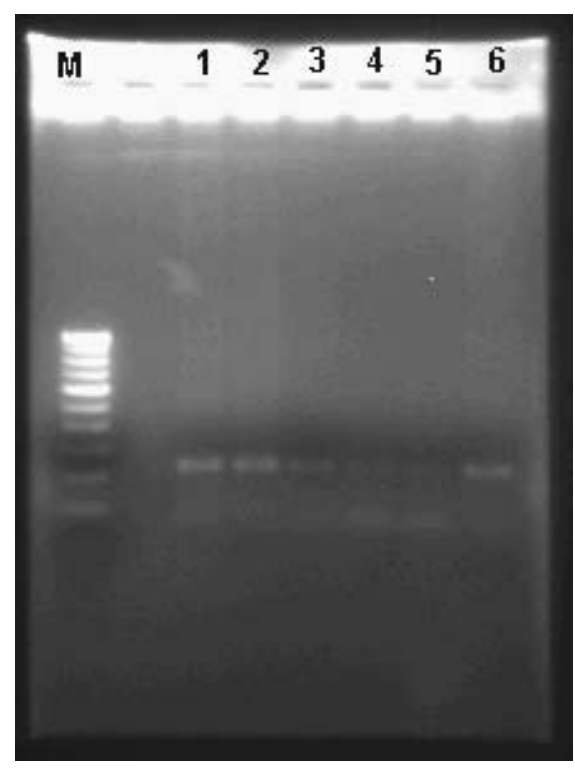

Fig. 3. PCR products of sssamples 1 to 6 . M- 1000 base pairs DNA ladder, Lanes 1-6 shows an amplified product between 200 and 300bp.

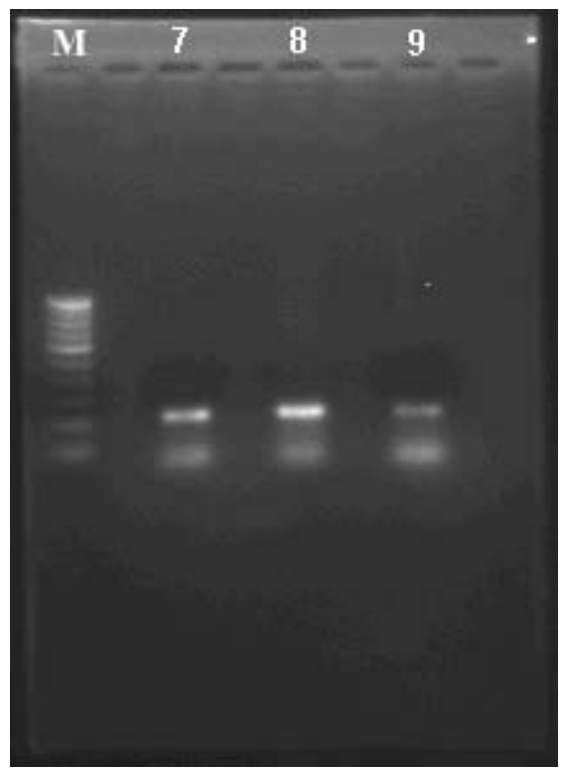

Fig. 4. PCR products of samples 7 to 9 . M- 1000 base pairs DNA ladder, Lanes 7-9 shows an amplified product between 200 and $300 \mathrm{bp}$. 
observed in samples 1,8 and 9 . All the other samples showed $\mathrm{C}$ genotype. Out of 9 individuals, $\mathrm{C}$ homozygotes were about $66.67 \%$ and $33.33 \%$ were C/T heterozygotes. (Fig.5, 6).

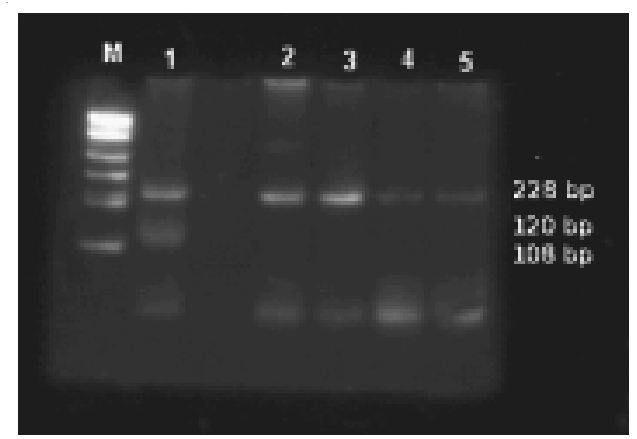

Fig. 5. Restriction digestion of PCR products of samples 1 to 5. M - 1000bp DNA ladder, Lane 1 shows C/T alleic variant as half of the PCR product is cut and the other half is uncut resulting in a mixture of 228,120 and $108 \mathrm{bp}$ fragments. Lane $2-5$ shows C/C allelic variant as the PCR product is not digested by Alu I enzyme resulting in a $228 \mathrm{bp}$ fragment.

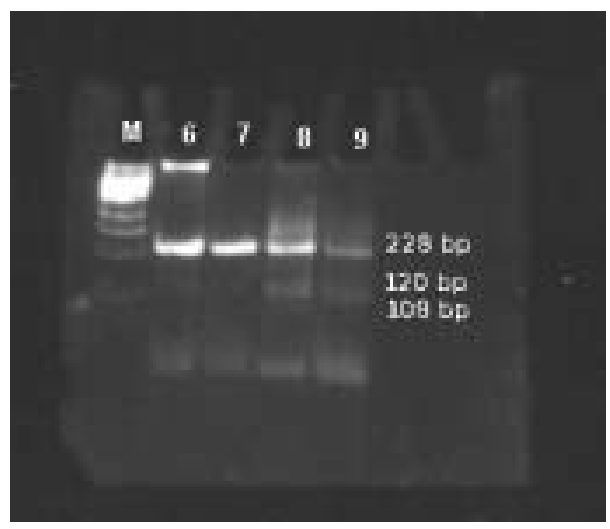

Fig. 6. Restriction digestion of PCR products of samples 6 to 9. M - 1000bp DNA ladder, Lanes 8-9 shows C/T alleic variant as half of the PCR product is cut and the other half is uncut resulting in a mixture of 228,120 and $108 \mathrm{bp}$ fragments. Lane 6-7 shows C/C allelic variant as the PCR product is not digested by Alu I enzyme resulting in a $228 \mathrm{bp}$ fragment.

\section{DISCUSSION}

The $\mathrm{C} / \mathrm{T}$ heterozygote provides protection against osteoporosis. Studies carried out by Taboulet et al. (1998) reveals the fact that the calcitonin receptor polymorphism is associated with a decreased fracture risk in post-menopausal women. Hence the polymorphism of these alleles in various populations suggests that the risk of polygenic diseases associated with CTR variations which also vary in different populations. In the present study, frequency of $\mathrm{C}$ allele is much higher than T allele in South Indians The Caucasians have much higher frequency of $\mathrm{T}$ allele but in African Americans and Hispanic, both alleles are almost equal. The Japanese and Chinese predominantly carry $\mathrm{C}$ allele. In this study, the $\mathrm{T}$ allele i.e., $\mathrm{T}$ genotype was completely absent. The major genotype in South Indians was found to be $\mathrm{C} / \mathrm{T}$ heterozygotes with a low percentage of $\mathrm{C} / \mathrm{C}$ genotypes, which differs considerably from the genotypes observed in different populations. In Caucasians, T/T genotype was present in almost $60 \%$ of individuals with $\mathrm{C} / \mathrm{T}$ and CC accounting for $36 \%$ and $4 \%$ respectively. It may be noted that heterozygous $\mathrm{C} / \mathrm{T}$ genotypes are usually less than $50 \%$ in Africans and Asians. Among Indian populations, T/T was found to be less in North Indians but almost absent in South Indians. The $\mathrm{C} / \mathrm{T}$ heterozygotes are high when compared to other populations.

\section{CONCLUSION}

Diseases like osteoporosis and urolithiasis are likely to result from combination of genetic variations in several genes. In CTR gene itself, according to Wolfe et al. (2003) 10 more polymorphisms have been identified but Codon 447 change brings about alteration in a key amino acid, which may have bearing on functional role of the receptor. So far studies of CTR with disease association are rather limited to Italians and Asian populations. In Indian populations, especially in the North Indians the T/T allele was low but in the South Indians it was totally absent. Hence this difference can be a major breakthrough to study the calcium metabolism involved disorders in both the populations.

\section{ACKNOWLEDGMENTS}

We sincerely thank Dr. Chenraj Jain, Chairman, Jain Group of Institutions, Bangalore, India, for providing us with all the facilities required for our work. We also thank the staff members and the non-teaching staff for helping us in the project. We thank Mr. Vimalkumar for guiding us in this project. 


\section{REFERENCES}

Chambers TJ, Magnus CJ 1982. Calcitonin alters behaviour of isolated osteoclasts. J Pathol, 136: 27-39.

Chen WJ, Armour S, Way J et al. 1997 Expression, cloning and receptor pharmacology of human calcitonin receptors from MCF-7 cells and their relationship to amyl in receptors. Mol Pharmacol, 52: 1164-1175.

ChenWC, Wu HC, Lu HF et al. 2001. Calcitonin receptor gene polymorphism: A possible genetic marker for patients with calcium oxalate stones. Eur Urol, 39: 716-719.

Copp DH 1992 Remembrance: Calcitonin discovery and early development. Endocrinology, 131: 1007 1008 .

Federal Bureau of Investigation 1993 RFLP Manual, U.S. Government.

Lin HY, Harris TL, Flannery MS et al. 1991 Expression cloning of an adenylate cyclase-coupled calcitonin receptor. Science, 254: 1022-1024.

Masi L, Becherini L, Gennari L et al. 1998. Allelic variants of human calcitonin receptor: Distribution and association with bone mass in post menopausal Italian women. Biochem Biophys Res Commun, 245: $622-626$

Mittal R.D, H.K. Bid and B. Mittal 2003. Polymorphism of Codon 447 Calcitonin Receptor Gene in North Indians Int J Hum Genet, 3(3): 175-177

Nakamura M, Zhang Z, Shan L et al. 1997. Allelic variants of human calcitonin receptor in the Japanese population. Hum Genet, 99: 38-41.

Reginster JY 1993. Calcitonin for prevention and treatment of osteoporosis [Review]. Am J Med, 95: 44S-47S.

Sambrook J, Fritsch EF, Maniatis T 1989. Molecular Cloning: A Laboratory Manual, 2nd edition. Cold Spring Harbor: Cold Spring Harbor Laboratory Press. Taboulet J, Frenkian M, Frendo JL et al. 1998. Calcitonin receptor polymorphism is associated with a decreased fracture risk in post-menopausal women. Hum Mol Genet, 7: 2129-2133.

Wolfe III LA, Fling ME, Xue Z et al. 2003. In vitro characterization of a human Calcitonin receptor gene polymorphism. Mutation Research, 522: 93105 